\title{
Comparison of radial growth rate of mycorrhizal fungi isolated from 43 species of northern orchids
}

\author{
BEN R. LINDÉN
}

\begin{abstract}
LINDÉN, B.R. 1988: Comparison of radial growth rate of mycorrhizal fungi isolated from 43 species of northem orchids. - Karstenia 28:19-25.

The investigation is part of a study devoted to the propagation of Scandinavian orchids. Endophytes from the roots of 43 orchid populations and, for comparison, from Moneses uniflora and four saprophytic fungi were isolated and the growth rates measured. The rates recorded ranged from 1.1 to $9.6 \mathrm{~mm}$ per 24 hours. The growth-retarding effect of tannin was also investigated. The response varied from total inhibition to no retarding effect. It is suggested that the differences in growth rates and response to retardants, which both seem to be dependent on the host taxonomy and ecology, can be of use in identifying the mycorrhizal endophytes.

Instead of the conventional isolating methods involving prolonged disinfection, the orchid roots were merely washed in soapy water, subjected to a high-pressure water jet, cut into segments and plated on plain water-agar medium. Contaminant-free cultures were easily achieved in this manner. Water-agar was also used for maintenance of cultures and growth rate observations.
\end{abstract}

Ben R. Lindén, Söilibacka 25A 6, SF-02180 Esbo, Finland

The investigation is part of a study devoted to the propagation of Scandinavian orchids. As reported by Lindén (1980), most of the propagation was performed using seeds in aseptic and axenic culture. As orchids in their natural habitat are known to be infected by mycorrhizal endophytes, it was desirable to study the effect of introducing the endophyte into a previously axenic culture. It was therefore necessary to build up a collection of orchid root endophytic isolates.

In culturing the endophytes, repeatable differences in growth rates were observed. The adoption of wateragar as a medium for isolation and culture of the endophytes was decided on after attempts to decontaminate Calypso bulbosa root and "bulb" fragments which were already in culture and infected by bacteria and moulds. Successive transfers to water-agar medium resulted in mould- and bacteria-free culture of the endophyte. It also became apparent that the fungus grew well on this nutrient-free medium.

Infection of the axenically grown orchid plants with an endophyte mostly led to the death of the plant, which was overwhelmed by the fungus, as has been reported by others, Williamson et al. (1970). In a trial run in which the plant and endophyte were grown simultaneously on water-agar, the plants survived for several weeks. To moderate the vigorous growth of the endophyte, tannin was added as a retardant to a medium in which the nutrients had already been decreased to half the normal content. Tannin was chosen as being a natural compound with known antifungal properties, Harborne (1964). These measures did not increase the survival rate of the orchid plants. Marked differences in the response to tannin were, however, observed for several endophytes and therefore included in this study on growth rates.

\section{Material and methods}

\section{Orchid material}

The orchids, collected from various regions of Finland, Norway and Sweden, are listed in Table 1 with the provenience of the host and a general indication of the part of the country from which the host came, for instance NW. Fi = north west Finland. The biotope of the plant material is also indicated. 
Table 1. Growth rates of endophytes. Symbols and abbreviations: $\mathrm{Fi}=$ Finland, No $=$ Norway, $\mathrm{Sw}=\mathrm{Sweden}$, $\mathrm{C}=$ central, $\mathrm{F}=$ forest, $\mathrm{M}=$ meadow, grassland, $\mathrm{AM}=$ alpine meadow, $\mathrm{W}=$ wet meadow, marsh. Culture medium: 10 per cent Agar (Bacto) in water. Tannin (Merck) conc. $1 \mathrm{gr} / 1000 \mathrm{ml} . \mathrm{n}=$ number of observations, $S=$ standard deviation, $N=$ number of observations, $\mathrm{K}=$ number in group, $\overline{\mathrm{X}}=$ average growth rate, $\overline{\mathrm{X}}=$ mean of averages in group, $-=$ tannin test not performed, $*=$ only average growth rate (not included in the statistical calculations), $\bar{s}=\sum \frac{(n-1) s^{2}}{N-K}=$ deviation in group.

\begin{tabular}{lcccc}
\hline Mycorrhizal host & $\begin{array}{c}\text { Provenience } \\
\text { of host }\end{array}$ & $\begin{array}{c}\text { Bio- } \\
\text { tope }\end{array}$ & $\begin{array}{c}\text { Reduction of growth rate } \\
\text { by tannin as fraction } \\
\text { of normal rate }\end{array}$ & $\begin{array}{c}\text { Radial growth rate } \\
\text { on water-agar medium }\end{array}$ \\
\end{tabular}

I Slow-rate group

1 Dactylorhiza incarnata ssp. cruenta

2 Pseudorchis albida

3 Cypripedium reginae

4 Dactylorhiza incarnata ssp. ochroleuca

5 Cypripedium calceolus

6 Dactylorhiza maculata 1

7 Platanthera chloranta

8 Dactylorhiza maculata 2

9 Dactylorhiza incarnata

10 Epipactis palustris

$\begin{array}{ll}\text { SE Sw } & \text { W } \\ \text { C No } & \text { AM } \\ \text { Cult. } & \text { Cult. } \\ \text { SE Sw } & \text { W }\end{array}$

SW Fi

E $\mathrm{Fi}$

SE Sw

E $\mathrm{Fi}$

NW Sw

$\mathrm{SW} F i$

F
F
F
F
W
W

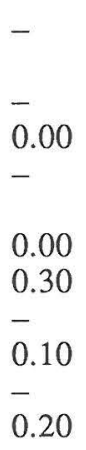

$\begin{array}{cll}2 & * & 1.1 \\ 5 & 0.19 & 1.1 \\ 5 & 0.67 & 1.3 \\ 4 & 0.24 & 1.3 \\ & & \\ 2 & * & 1.4 \\ 5 & 0.36 & 1.5 \\ 4 & 0.26 & 1.5 \\ 6 & 0.10 & 1.6 \\ 4 & 0.52 & 1.7 \\ 4 & 0.08 & 1.8 \\ \overline{\mathrm{S}}=0.34, \overline{\bar{X}}=1.4, \overline{\mathrm{S}} / \overline{\bar{X}}=0.24\end{array}$

II Medium-rate group

11 Epipactis helleborine
12 Corallorhiza trifida
13 Cephalanthera longifolia
14 Dactylorhiza maculata 2
15 Dactylorhiza maculata 1
16 Nigritella nigra
17 Orchis militaris
18 . Orchis morio
19 Dactylorhiza maculata
20 Dactylorhiza incarnata
21 Epipactis atrorubens
22 Chamorchis alpina
23 Orchis spitzelii
24 Dactylorhiza maculata
25 Dactylorhiza maculata
26 Platanthera bifolia
27 Calypso bulbosa
28 Dactylorhiza sambucina
29 Gymnadenia conopsea
30 Gymnadenia odoratissima
31 Platanthera bifolia
32 Gymnadenia conopsea
33 Anacamptis pyramidalis
34 Orchis mascula

E $F i$

SW Fi

SE Sw

SW Fi

SW Fi

C No

SE SW

SE SW

$\mathrm{SW} F \mathrm{Fi}$

SE Sw

E $\mathrm{Fi}$

JC No

SE Sw

SE Sw

C No

SE SW

NW Fi

SW Fi

NW SW

SE Sw

E $\mathrm{Fi}$

SE Sw

SE SW

SE SW

F

F

M

F

$\mathrm{F}$

M

M

M

F

W

F

AM

M

F

F

F

F

M

W

F

F

F

M

M $\overline{0} .35$

0.15

0.00

0.45

$-$

0.65

0.00

0.20

0.95

0.05

0.20

0.35

0.50

0.25

0.05

0.30

0.55

0.00

0.30

0.50
0.89

0.66

0.31

0.54

0.61

0.52

0.37

$*$

0.65

0.54

0.26

0.81

0.57

1.12

0.48

*

0.87

0.97

1.06

$*$

0.88

*

*

0.57
2.2

2.4

2.7

2.7

2.8

2.8

2.8

3.0

3.1

3.7

3.7

3.8

3.8

3.9

3.9

3.9

4.0

4.2

4.2

4.3

4.3

4.5

5.0

5.2

(contd.) 
Table 1. (contd.)

\begin{tabular}{|c|c|c|c|c|c|c|}
\hline \multirow[t]{2}{*}{ Mycorrhizal host } & \multirow[t]{2}{*}{$\begin{array}{c}\text { Provenience } \\
\text { of host }\end{array}$} & \multirow[t]{2}{*}{$\begin{array}{l}\text { Bio- } \\
\text { tope }\end{array}$} & \multirow{2}{*}{$\begin{array}{l}\text { Reduction of growth rate } \\
\text { by tannin as fraction } \\
\text { of normal rate }\end{array}$} & \multicolumn{3}{|c|}{$\begin{array}{c}\text { Radial growth rate } \\
\text { on water-agar medium }\end{array}$} \\
\hline & & & & $\mathrm{n}$ & $S$ & $\mathrm{x} \mathrm{mm} / 24 \mathrm{~h}$ \\
\hline 35 Platanthera bifolia & NW Fi & $\mathrm{F}$ & 0.95 & 4 & 0.56 & 5.3 \\
\hline 36 Platanthra bifolia & $\mathrm{SW} F i$ & $\mathrm{~F}$ & 0.95 & 9 & 1.03 & 6.2 \\
\hline
\end{tabular}

\section{Fast-rate group}

37 Goodyera repens
38 Gymnadenia conopsea
39 Listera ovata
40 Herminium monorchis
41 Cephalanthera rubra
42 Liparis loeselii
43 Orchis ustulata

Pyrolaceae:

\section{Moneses uniflora}

Saprophytic fungi:

45 Lycoperdon perlatum
46 Agaricus arvensis
47 Coprinus comatus
48 Macrolepiota procera

$\begin{array}{ll}\text { SW } & \text { Fi } \\ \text { SE } & \text { Sw } \\ \text { SW } & \text { Fi } \\ \text { SE } & \text { Sw } \\ \text { SE } & \text { Sw } \\ \text { SE } & \text { Sw } \\ \text { SE } & \text { Sw }\end{array}$

F

M

F

W

F

W

M

$$
\begin{aligned}
& 0.00 \\
& - \\
& - \\
& 0.65 \\
& 0.65 \\
& \overline{0} \\
& 0.80
\end{aligned}
$$

$\begin{array}{ccc}4 & 2.20 & 6.3 \\ 5 & 1.30 & 6.9 \\ 5 & 0.95 & 8.1 \\ 3 & * & 8.5 \\ 5 & 0.86 & 8.7 \\ 4 & 1.32 & 9.0 \\ 4 & 0.85 & 9.6 \\ \overline{\mathrm{S}}=1.21, \overline{\bar{X}}=8.2, \overline{\mathrm{S}} \overline{\bar{X}}=0.15\end{array}$

3

5.0

$\begin{array}{llll}- & 2 & * & 0.9 \\ - & 6 & 0.55 & 1.0 \\ - & 2 & * & 1.6 \\ - & 3 & * & 2.4\end{array}$

The nomenclature follows Davies et al. (1983).

For comparison a non-orchid, Moneses uniflora (L) A. Gray, was chosen, which has seeds almost indistinguishable from those of orchids and which is known to be heavily infected by mycorrhiza (Ramsbottom 1923).

Mycelia of four saprophytic fungi: Agaricus arvensis, Schaeff., Coprinus comatus, (Muell.: Fr.) S.F. Gray, Macrolepiota procera (Scop.: Fr.) Sing. and Lycoperdon perlatum Pers., were also isolated and cultured for growth rate comparison.

\section{Isolation methods}

At first, the orchid root endophyte was isolated by methods similar to those proposed by Burgeff (1936), i.e. the roots were cut off from the plant, and brushed and washed before disinfection in 1 per cent sodium hypochlorite for 15-20 min. After being washed in sterial water, the roots were dissected under the microscope and pelotons of the endophyte were extricated from the root cells or whole sections of the root cortex were used for inoculation on the growth medium.

Later, when water-agar was used for isolation and culture, the roots were not sterilized with hypochlorite but only brushed and washed with soap and water and then subjected to a high pressure jet of tapwater. After drying under sterile conditions the roots were cut into one centimetre sections and plated on the medium. This method was also used from Moneses uniflora.

In two to five days of incubation, hyphae long enough to be picked up and replated grew out of the 
root segments. It has been reported (Burgeff 1909) and was also observed in the microscope in the present study that the infection of the orchid root is mostly concentrated to the third to fifth layer of the cortical cells, counted from the epidermis. This may have been responsible for the fact that most of the fungal hyphae were observed to grow out of the cut ends of the root segments. Penetration of the root by the hyphae seems to be more rapid in the lateral than in the transverse direction; in the latter direction the epidermal cells may act as a barrier.

For isolation of fungal mycelia, freshly collected fruit bodies were broken open and fragments were cut out from the inner part, using a sterile scalpel.

\section{Culture media}

At the beginning various media were tested as given by Booth (1971). The following substances were tested as carbohydrate sources: filter paper (10 gr), fresh Bintje potato (200 gr), oatmeal (5 gr), amylum starch, and Na-CMC (sodium carboxy methyl cellulose) (5 gr), all per $1000 \mathrm{ml}$ of medium.

Subsequently only two media were used:

1. Water-agar
Agar (Bacto)
Aq.dest.
$10 \mathrm{gr}$
$1000 \mathrm{ml}$

2. Mineral enriched extract of oatmeal

$\begin{array}{lr}\mathrm{MgSO}_{4} \cdot 7 \mathrm{H}_{2} \mathrm{O} & 250 \mathrm{mg} \\ \mathrm{NH}_{4} \mathrm{SO}_{4} & 250 \mathrm{mg} \\ \text { FeEdTA } & 3 \mathrm{mg} \\ \text { Oatmeal } & 5 \mathrm{gr} \\ \text { Agar (Bacto) } & 10 \mathrm{gr} \\ \text { Aq.dest. } & 1000 \mathrm{ml}\end{array}$

The oatmeal extract was prepared from commercial rolled oats ground to powder and cooked for $20 \mathrm{~min}$. in $200 \mathrm{ml}$ of aq.dest. after which the gruel was filtered through a fine-mesh Philips sieve for filtering coffee. Bacto-agar (Difco), considered to be very pure, was mainly used. In a few cases other agars were tried but with no noticeable difference in endophyte behaviour.

The effect of tannin as a growth retardant was tested by adding this substance to a medium of the following composition (half strength mineral content for lower growth vigour):

$\begin{array}{lr}\mathrm{MgSO}_{4} \cdot 7 \mathrm{H}_{2} \mathrm{O} & 125 \mathrm{mg} \\ \mathrm{NH}_{4} \mathrm{SO}_{4} & 125 \mathrm{mg} \\ \mathrm{Na}-\mathrm{CMC} & 1 \mathrm{gr} \\ \text { Agar (Bacto) } & 10 \mathrm{gr} \\ \text { Aq.dest. } & 1000 \mathrm{ml}\end{array}$

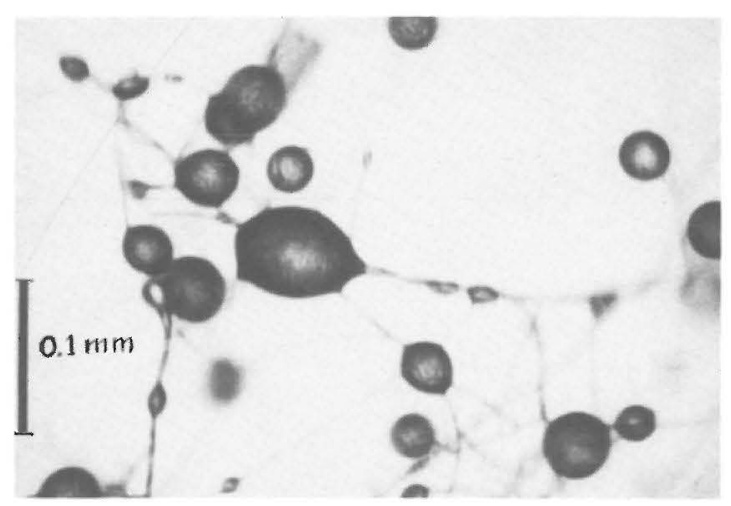

Fig. 2. Spore-filled droplets on aerial hyphae of endophyte isolated from Epipactis helleborine.

Three concentrations of tannin (Merck) were used: $0.1,0.5$ and 1.0 gr per $1000 \mathrm{ml}$ of medium. Later, only $1 \mathrm{gr}$ of tannin per $1000 \mathrm{ml}$ of medium was used, as this concentration proved to be high enough to retard growth but not too high to cause total inhibition. Null tests, with no addition of retardant to the medium, were used for comparison. All media were autoclaved for $20 \mathrm{~min}$. at $120^{\circ} \mathrm{C}$ and poured into $9 \mathrm{~cm}$ disposable Petri dishes, which after inoculation were closed with a double strip of Parafilm, which prevented drying for at least two years. The endophyte cultures were kept in about $20^{\circ} \mathrm{C}$ in the dark. Replating was usually performed every 6 to 12 months.

\section{Results}

The undefined carbohydrate sources, potato and oatmeal, caused the most vigorous growth, filling the Petri dishes with dense mats of woolly mycelia in one week. Vigorous growth was also induced by mineral nutrients added to media with amylum starch, NaCMC or filter paper. A week after initial inoculation, the woolly mycelium was white or very lightly tinted, but in a few weeks it darkened, especially in the case of isolates from the rhizomatous orchids of the genera Cypripedium, Cephalanthera and Epipactis.

On plain water-agar, growth was sparse, with a few hyphae per square millimetre of medium, the hyphae either progressing along the surface or making aerial jumps. Usually the growth rate fell markedly within a week of the initial inoculation.

On water-agar pelotons, the curly formations (Fig. 1A) depicted by Bernard (1909), were regularly ob- 

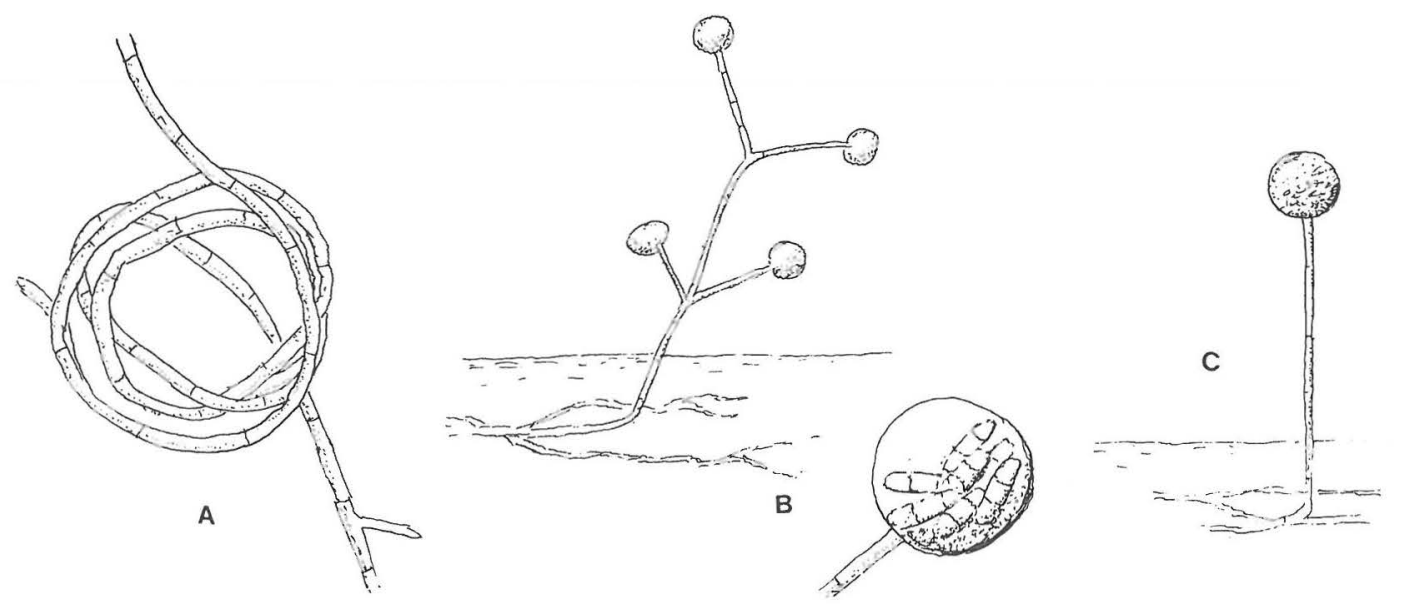

Fig. 1A-C. - A: Skein-formed peloton on surface of medium. - B: Aerial hyphae of Calypso bulbosa with droplets filled with three-celled spores. - C: Aerial hyphae of Platanthera bifolia.

served in most of the cultures. Spore formation, which was rare in the case of nutrient-rich media, was abundant on both the surface and in liquid drops exuded from the tips of the aerial hyphae. Isolates taken from Calypso bulbosa, for instance, produced multi-branched aerial hyphae with droplets of $0.03 \mathrm{~mm}$ at the ends containing 3 to 6 spores with 2 to 5 cells (Fig. 1B). Platanthera bifolia isolates, on the other hand, produced three-celled spores about $0.02 \mathrm{~mm}$ long; these were concentrated in droplets on the tips of unbranched aerial hyphae (Fig. 1C). In addition, tightly packed spores were observed on the surface of the medium. Epipactis helleborine isolates produced spore-filled droplets about $0.05 \mathrm{~mm}$ in diameter (Fig. 2). In many cases in which the cultures were kept for more than 6 months without replating, only the spores remained, the hyphae having disintegrated. These spores stayed viable up to at least two years.

After the inoculum had been placed in the centre of the dish, the spreading of the mycelium was measured two to four times for about 10 days. The maximum spread was used as a measure of the growth rate, which was expressed as $\mathrm{mm}$ in 24 hours. The medium-dependent differences in growth rate were negligible, but were more easily measured on the transparent water-agar medium. The growth rates of the isolates on water-agar are presented in Table 1, in which the orchid mycorrhizae are divided into three groups on the basis of their growth:

1. Slow growers, $1.0-1.8 \mathrm{~mm}$ per 24 hours

2. Medium-rate growers, $2.0-5.3 \mathrm{~mm}$ per 24 hours

3. Fast growers, $6.3-9.0 \mathrm{~mm}$ in 24 hours

The number of measurements (n) per isolate ranges from two to nine and the standard deviation $(\mathrm{S})$ is only reported when more than three measurements were made. In all cases the average growth rate $\overline{\mathrm{X}}$ is given. The growth rate averages are depicted in Fig. 3, which also gives the upper and lower limits of two standard deviations.

In the case of Dactylorhiza incarnata, D. maculata, Gymnadenia conopsea and Platanthera bifolia, plants from several localities were used for interspecies comparison. The records of the host biotope give an idea of the surroundings in which the orchid-mycorrhiza complex usually grows. The mycorrhizal fungus of Moneses uniflora belonged to the group of medium rate growers (5.0 mm per 24 hours) and the saprophytic fungi, with the exception of Macrolepiota procera, definitely had slow radial growth (0.9$1.6 \mathrm{~mm}$ per 24 hours).

In Table 1 the reduction of growth by tannin is expressed as a decimal fraction of the normal growth rate, i.e. 0.00 stands for no effect of tannin, as in the case of Orchis morio (18), and 0.95 stands for nearly 


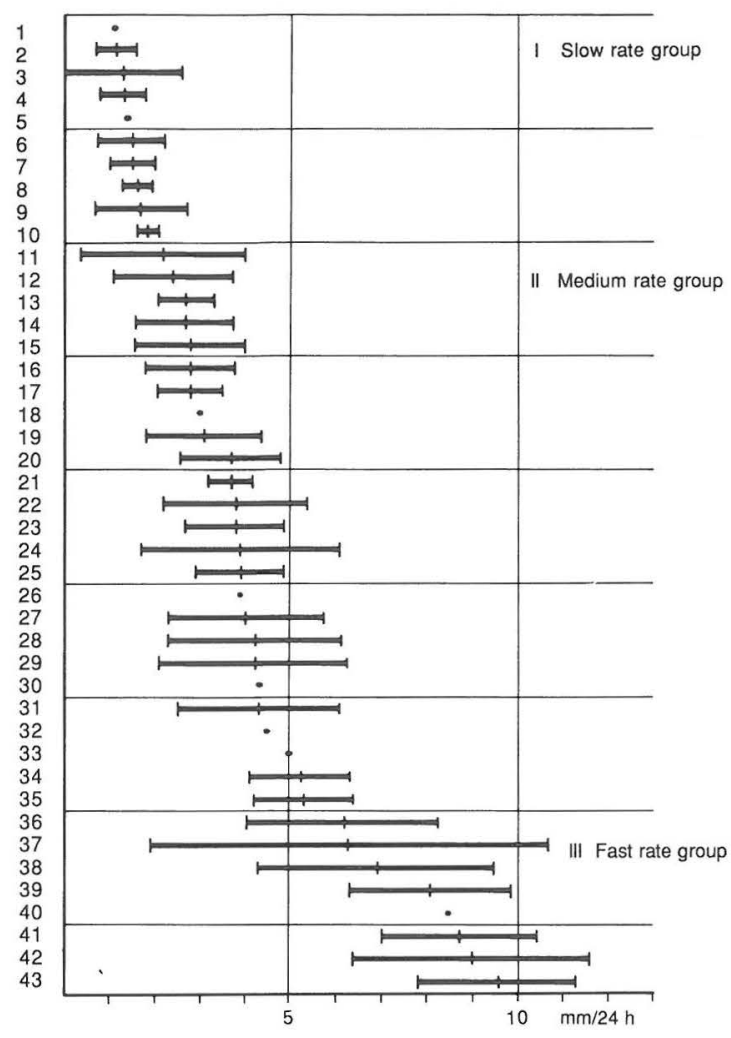

Fig. 3. Average growth rates of 43 mycorrhizal fungi with the upper and lower limits of two standard deviations marked where applicable. Host identified by number, see Table 1.

complete inhibition, as in the case of Platanthera bifolia $(35,36)$. When the space for the effect of tannin is left empty $(-)$, no tests were performed. With tannin two phenomena were observed: Strong inhibition of growth was in the majority of cases connected with a marked darkening of the medium. With tanninfree medium, spreading of the mycelium usually started 1-2 days after inoculation and reached a maximum rate before the 10th day of growth. In the case of tannin, the initial growth rate was minimal and the maximum rate was reached after more than 10 days. It seemed as if a certain time was necessary for the fungal metabolism to adapt to the presence of tannin.

To test the ability of the endophyte to enhance germination, Platanthera bifolia seeds, which had poor axenic germination, were used with fungal iso- late from the same species. Symbiotic germination was clearly superior in amount and speed to the axenic.

\section{Discussion}

Parallel tests were performed on several orchid hosts, using first the method of teasing out the fungal peloton from the root cell and then, for comparison, the simplified method of plating the root segments directly on the medium. In the two cases the results were identical; the endophytes looked alike and grew in the same manner. Bacterial and mould infections were seldom observed after plating the root segments, which shows the effectiveness of the high-pressure water-jet. The jet peels off the epidermal layer of the root, which probably eliminates many surface contaminants. The germination-enhancing ability of the fungal isolate was tested on seeds of Platanthera bifolia with positive results. These observations can be taken as indications of the usefulness of the simplified method.

The growth rates on plain water-agar and the response to the addition of tannin are markedly different for many of the fungal isolates and may be related to the ecology (Curtis 1939) and taxonomy of the host. In the present study the isolates from Cypripedium calceolus (5) and C. reginae (3), the sole members of the order Diandrae, were both extremely slow growers and virtually unaffected by tannin.

Isolates taken from two populations of Dactylorhiza maculata $(6,8)$ of the fuchsii type grew much more slowly on water-agar than isolates from five $D$. maculata populations of the ericetorum type $(14,15$, 19, 24, 25).

Fast growing fungal isolates from Cephalanthera rubra (41), Orchis ustulata (43) and Herminium monorchis (40) were greatly retarded by tannin, and it could be concluded that the fast growers were as a rule sensitive to this substance. Though a fast grower, the endophyte from Goodyera repens (37) was not affected by tannin. In nature this endophyte is known to grow in spruce needles (Mollison 1943), which could explain its tolerance of tannin. The medium-rate endophytes isolated from Platanthera bifolia $(26,31,35,36)$ collected from several localities showed unexpected differences in their response to tannin, in spite of their identical appearance and growth rate on plain water-agar. This may indicate the existence of ecotypes in the same species.

In conclusion, it is suggested that the differences in growth rates on plain water-agar and the response to tannin of the endophytes could be used as an additional tool for identifying mycorrhizal fungi of orchids. 
Acknowledgements. I am indebted to Professor Liisa Simola at the Department of Botany of the University of Helsinki, who provided working facilities for this study.

\section{References}

Bernard, N. 1909: L'évolution dans la Symbiose. - Ann. Sci. Nat. 9:1-96.

Booth, C. (ed.) 1971: Methods in microbiology 4. - 795 pp. London-New York.

Burgeff, H. 1909: Die Wurzelpilze der Orchideen. - 220 pp. Jena.

- 1936: Samenkeimung der Orchideen. - 312 pp. Jena.

Curtis, J. 1939: The relation of specificity of orchid mycorrhizal fungi to the problem of symbiosis. - Am. J. Bot. 26:390-399.

Davies, P., Davies, J. \& Huxley, A. 1983: Wild orchids of Britain and Europe. - $256 \mathrm{pp}$. London.

Harborne, J.B. 1964: Biochemistry of Phenolic compounds. - 618 pp. London-New York.

Harley, J.J. 1969: The biology of Mycorrhiza. - 233 pp. London.

Lindén, B. 1980: Aseptic germination of seeds of Northern terrestrial orchids. - Ann. Bot. Fennici 17:174-182.

Mollison, J.E. 1943: Goodyera repens and its endophyte. - Trans. Bot. Soc. Edinb. 33:391-403.

Ramsbottom, J. 1933: Orchid mycorrhiza. - The British Myc. Soc. Trans. Vol. VIII: 28-61.

Williamson, B. \& Hadley, G. 1970: Penetration and infection of orchid protocorms by Thanatephorus cucumeris and other Rhizoctonia isolates. — Phytopat. 60:10921906.

Accepted for publication

on 10 October 1988 